\title{
JOHN STUART MILL ON MATRIMONIAL PROPERTY AND DIVORCE LAW REFORM
}

\author{
Henry Kha*
}

\section{ABSTRACT}

Victorian England is often seen as an era of stability for marital and family life. In reality, it was a period of significant legal and social change that opened the way for the introduction of the modern family court system. It was a time and place where women had very few legal rights in regards to divorce and matrimonial property. John Stuart Mill was a key proponent for the advancement of women's rights in the Victorian period. The article argues that Mill was an advocate for equal opportunity for women based on ideals of liberty, but this was based on a gender complementarian division of roles within the family. The article focuses on Mill's major work on women's rights, The Subjection of Women. Mill presented a radical piece of writing based on principles of equality as a source of moral progress amidst the reactionary politics of Victorian England.

Keywords: John Stuart Mill; Victorian England; divorce law; marriage law; Married Women's Property Act; law reform

\section{Introduction}

The political philosophy of liberalism played a significant role in shaping Mill's views on marriage and divorce. This is most evident in Mill's application of the

* Lecturer, Macquarie Law School, Macquarie University. 
"tyranny of the majority" theory and the "no harm" principle from On Liberty. Mill condemned the fact that men could not be charged for committing marital rape. ${ }^{1}$ He criticised the artificial distinction between public and private by suggesting it was ludicrous to suggest that someone could be a public democrat and a private despot. ${ }^{2}$ Instead, Mill argued for the avoidance of the tyranny of the majority that "establishes a despotism over the mind, leading by natural tendency to one over the body." ${ }^{3}$ The statement was a criticism of the wide-spread belief in the doctrine of coverture that led men to believe that they had a natural right to rule over women as if she was a possession. ${ }^{4}$ The doctrine of coverture translated into denying a married woman independent legal personality, thus creating a situation where a wife could not legally-speaking be raped by her husband.

A fundamental element of liberalism is the "no harm" principle. Mill outlines: "That the only purpose for which power can be rightfully exercised over any member of a civilized community, against his will, is to prevent harm to others." 5 The fact that the law denied women basic rights, such as legal personhood in marriage, ${ }^{6}$ feme sole property rights, ${ }^{7}$ and the right to divorce from an abusive relationship, ${ }^{8}$ interfered with the liberty of women. Thus, Mill argued that the law promoted harm towards women and believed this could be remedied by removing gender inequality from the law, which would improve the state of women, free women from the harmful excesses of the law and advance the progress of society. ${ }^{9}$ These liberal ideas formed the foundation for Mill's philosophy against the subjection of women.

There has been some academic debate that has attempted to class Mill as a particular type of feminist. ${ }^{10}$ A number of scholars, such as the ones mentioned below, have attempted to categorise Mill from the perspective of either a liberal or a radical feminist critique. The former promotes the idea that Mill's political liberal theoretical framework influenced his conclusion that women should be afforded equality of opportunity. For example, Zillah Eisenstein states as follows: "Mill reiterates the importance of the equality of opportunity doctrine in On the Subjection of Women

1 The origins to the exemption on marital rape can be traced to the legal treatise of Matthew Hale, an eighteenth century English legal jurist. See Hale 1736: 629.

2 Mill 1984b: 299; Morales 2007: 64.

3 Mill 1977: 302.

4 The origins of the doctrine of coverture can be traced to the legal treatise of William Blackstone, an eighteenth century English legal jurist. See Blackstone 2016.

5 Mill 1977: 223.

6 Blackstone 2016: 284.

7 Stretton \& Kesselring 2013: 6-7.

8 Matrimonial Causes Act 1857, s 27. See Kha and Swain 2016: 319.

9 Mill 1984b: 293-294.

10 Eisenstein 1981: 127; Himmelfarb 1974: 173-174; Morales 2005: 99-100; Tong 2009: 20; Tulloch 1989: xvi. 
and argues that one's birth should not determine one's station in life." 11 The liberal feminist critique views Mill as a law reformer rather than a revolutionary. ${ }^{12}$ The latter views Mill as a gender egalitarian who argued that women should be provided substantive equality and not simply equality of opportunity. Thus, for example, Maria Morales argues that Mill promoted a perfect equality between the sexes as a substantive relational ideal. ${ }^{13}$ The shortcoming of the radical feminist critique is its presentist agenda of attempting to portray Mill as a gender egalitarian to fit its narrative of the modern women's movement. Gertude Himmelfarb states:

As the women's movement has currently chosen to emphasize equality rather than liberty, so it has distracted attention from the individualistic nature of Mill's argument. For Mill the central problem was the individual: how to give to the individual woman the same degree of liberty enjoyed by the individual man, how to make more complete individuals of both women and men. ${ }^{14}$

An analysis of the legal history of women's rights in Victorian England demonstrates that the radical feminist characterisation of Mill is ahistorical; whereas the liberal feminist critique is more grounded in the legal historical context. Mill was a product of the Victorian era and believed in a gender-based division of roles with the husband acting as the breadwinner and the wife serving as the primary care-giver to the children..$^{15}$ There is also a gap in the scholarship on analysing Mill's philosophical ideas from the perspective of the legal history of Victorian England. Dale Miller, for example, analyses Mill's ideals on the family, but does not seriously explore the legal history in significant depth. ${ }^{16}$ The analysis of the legal history is essential in understanding the role of the law in influencing the philosophy of Mill and explaining how his views influenced the development of the law. This article will argue that Mill was a gender complementarian in the area of family life, who believed in equal opportunities for women. This shall be demonstrated through an analysis of the law in its historical context and the views Mill espoused in his writings. The focus will be on examining what Mill said himself and the development of the law during his time.

\section{The campaign for matrimonial property law reform}

In regards to matrimonial property rights, women could not own property feme sole until the enactment of the Married Women's Property Act 1882. Although the wife could still hold onto property under equity by means of a trust, the matrimonial property regime for most of the nineteenth century gave the husband almost absolute

11 Eisenstein 1981: 127. See also Himmelfarb 1974: 171.

12 Tong 2009: 20.

13 Morales 2005: 100.

14 Himmelfarb 1974: 174.

15 Mill 1984b: 297.

16 Miller 2017: 472-487. 
legal control of his wife's property after marriage. ${ }^{17}$ The campaign for married women's property rights emerged in the 1860 s, which saw the rise of a feminist campaign for greater recognition of women's legal rights. ${ }^{18}$ The issue of married women's property rights was tied to the wider campaign for women's suffrage. Mill played an important role in bringing attention to the injustice of denying married women the legal right to own property. His role as a politician was instrumental in the enactment of the Married Women's Property Act 1870.

The expansion of married women's property rights came to have a significant impact not only on the legal status of women, but also on the wider debate surrounding divorce law. Gender equality found in matrimonial property rights naturally prompted questions about gender equality in the grounds for divorce. Once married women obtained the right to equal access to matrimonial property, it raised questions about the right of married women to equal access to the grounds for divorce. Mary Lyndon Shanley states that " $[t]$ he end of coverture certainly ranks along with suffrage as the sine qua non of public recognition of women's autonomy and personhood". ${ }^{9}$ Indeed, the Married Women's Property Act 1882 gave wives equal property rights with their husbands, which elevated the legal and social status of women. The corollary of this legal change was the scrutiny of other glaring areas of sex discrimination, such as in the law of divorce. As Ann Sumner Holmes explains, a "[wife] appeared as her husband's equal rather than his ward. From this perspective, the double standard in the divorce laws seemed anachronistic". ${ }^{20}$ It would take another four decades after the abolition of coverture for the double standards in the grounds for divorce to be abolished. ${ }^{21}$ Nevertheless, the expansion of married women's property rights had made the repeal of the double standard in the grounds for divorce inextricably linked based on the promotion of women's rights and gender equality.

Feme sole for all women regardless of marital status was recognised in 1882. This motivated politicians, judges, lawyers and feminists to advocate for the removal of the double standard between genders in the grounds of divorce. Although married women could own property in equity under a trust, there was no legal recognition of the right of married women to own property at common law. In practice only wealthy and middle class women settled trusts in preparation for marriage, while most other women married without the protection of equity. ${ }^{22}$ Even when separated a married

17 Married women were deemed to be feme covert. Conversely, a woman who owned property in her own legal right was considered to be feme sole and therefore was discovert. However, the Court of Chancery recognised the married woman's right to separately own paraphernalia, such as clothing, jewellery and personal ornaments either gifted by friends, family members or the husband. See Holcombe 1983: 41.

18 Shanley 1989: 50.

19 Shanley 1986: 72.

20 Holmes 1995: 608.

21 Matrimonial Causes Act 1923. See Probert 1999a; Probert 1999b.

22 Dicey 1905: 381. 
woman was unable to live financially independently from her estranged husband, since the wife's earnings were the legal property of the husband. ${ }^{23}$ This problem was compounded by the fact that married women were unable to enter into their own contracts.

\section{Married Women's Property Act 1870}

The first major attempt to introduce property rights for married women was debated at the same time as the divorce legislation in 1856 and 1857. During the House of Lords Select Committee debates on the 1856 Divorce Bill, Lord Lyndhurst proposed to allow separated married women the right of feme sole, particularly the right of married women to keep their own earnings and to inherit property from estates..$^{24}$ This would help redress some of the inequalities faced when married women separated. The proposal was eventually recognised as sections 25 and 26 of the Matrimonial Causes Act 1857. In February 1857, Lord Brougham introduced the first Married Women's Property Bill into the House of Lords. This was a radical measure that proposed to grant all married women the rights of feme sole, including allowing married women to legally enter into contracts in their own name, create their own separate wills and keep their own earnings. ${ }^{25}$ The House of Commons followed suit in the middle of the year when Sir Erskine Perry and Richard Monckton Milnes introduced a similar Bill in order to remedy the financial exploitation of married women found in the doctrine of coverture. ${ }^{26}$

Lord St Leonard sensed that the Bill would be a highly divisive issue. The proposal undermined the longstanding doctrine of coverture by disrupting the traditional gender roles of male headship and female submission. ${ }^{27}$ Therefore, he successfully persuaded his colleagues to support his amendment to the Divorce Bill that provided the rights of feme sole to separated married women, whilst avoiding the potentially divisive issue of coverture. ${ }^{28}$ Lawrence Stone argues that there was a sense of irony in the success of Lord St Leonard's proposal, because it may have inadvertently curtailed the extension of this right to all women irrespective of marital status. ${ }^{29}$ Indeed, Parliament was able to dismiss further calls to extend the right of feme sole for a few decades. Lord St Leonard described the Bills that called for an extension of feme sole to all married women as a "mischievous one", and believed that his amendment was measured "going as far as was desirable, and so prevent a

24 HL Debate 26 Jun 1856, vol 142, cols 1968-1969.

25 HL Debate 3 Feb 1857, vol 144, cols 605-619.

26 HC Debate 14 May 1857, vol 145, cols 266-281.

27 HL Debate 25 May 1857, vol 145, col 800.

28 Idem at cols 806-808.

29 Stone 1995: 376. 
greater evil". ${ }^{30}$ The scope of feme sole was contained in order to ameliorate concerns over the abolition of the doctrine of coverture.

The campaign for married women's property rights initially subsided, but the matter soon re-emerged in the 1860s, which saw the emergence of a feminist campaign for the recognition of women's legal rights. ${ }^{31}$ The issue of married women's property rights was tied with the wider campaign for women's suffrage. Mill campaigned for the suffrage of women based on his belief that women should have equal rights to vote in order to enable women to effectively protect themselves against injustice and to broaden parliamentary representation that was hitherto ruled by an oligarchy. ${ }^{32}$ In 1869, Mill wrote in The Subjection of Women that "[t]o have a voice in choosing those by whom one is to be governed, is a means of self-protection due to everyone". ${ }^{33}$ Mill was also the Member for City and Westminster in the House of Commons between 1865 and 1868 and used his position to advocate for the feminist cause in Parliament. ${ }^{34}$

In 1866, Prime Minister Lord John Russell's Reform Bill was brought before Parliament. This was the most significant electoral law reform since the Reform Act 1832, which introduced "an essentially modern electoral system based on rigid partisanship and clearly articulated political principle". ${ }^{35}$ Leading feminist Barbara Leigh Smith Bodichon ${ }^{36}$ who was acting on the advice of Mill, successfully collected 1,499 signatures for a petition calling for the right of women to vote. ${ }^{37}$ Mill introduced an amendment to the Reform Bill by calling for "men" to be replaced with "persons," thereby attempting to enfranchise women on the same footing as men. ${ }^{38}$ However, the amendment was comfortably defeated by 196 votes to 73. ${ }^{39}$ Many MPs were uncomfortable with a radical change to the gender roles in Victorian society, particularly suggestions of equal rights for women. Samuel Laing encapsulated the feelings of those who were opposed to the Bill: "Now ... he hoped the day was far distant when our women should become masculine and our men effeminate." ${ }^{40}$ Although women were not given the vote, the Bill later passed into law as the Reform Act 1867. This enfranchised a significant proportion of the English borough electorate from 500,000 in 1866 to 1.25 million in $1871 .{ }^{41}$

Ibid.

Kinzer, Robson \& Robson 1992: 5.

Phillips \& Wetherell 1995: 412.

In 1857, Barbara Leigh Smith married Eugène Bodichon and took his surname.

Holcombe 1983: 115.

HC Debate 20 May 1867, vol 187, cols 817-829.

Idem at cols 843-845.

Idem at col 840.

41 Parry 1993: 217. 
A more organised feminist movement was created with the formation of women's suffrage committees across England. The issue of women's suffrage raised deeper questions about the wider legal rights of women in English society. During the 1860 s the women's suffrage movement gave rise to a renewed campaign for married women's property rights. ${ }^{42}$ Mill provided the philosophical framework and political impetus for the recognition of married women's property rights. Ann Robson states that "Mill's contribution to the women's movement cannot be overestimated". ${ }^{43}$ Mill argued that women should be entitled to the legal right to possess their own property regardless of their marital status. ${ }^{44} \mathrm{He}$ believed that the denial of property rights to married women was unjustly oppressive. Moreover, he saw it as unfair that the husband should possess total legal rights to matrimonial property in order to perpetuate the legal fiction of coverture. Mill states:

She can do no act whatever but by his permission, at least tacit. She can acquire no property but for him; the instant it becomes hers, even if by inheritance, it becomes ipso facto his. In this respect the wife's position under the common law of England is worse than that of slaves in the laws of many countries: by the Roman law, for example, a slave might have his peculium, which to a certain extent the law guaranteed to him for his exclusive use. ${ }^{45}$

Feminists played an important role in campaigning for reform of married women's property rights in the 1870 s and 1880 s. The first generation of feminists led by Bodichon in the 1850 s failed to bring about any meaningful reform of married women's property rights, and they disbanded soon after the Matrimonial Causes Act 1857 was passed. ${ }^{46}$

The second generation of feminists who campaigned for women's property rights was led by Elizabeth Clarke Wolstenholme Elmy, Josephine Grey Butler, Emilia Jessie Boucherett and Ursula Mellor Bright. They were actively involved in the second incarnation of the Married Women's Property Committee established in 1868. ${ }^{47}$ This time the feminist activities were centred in Manchester rather than London. The second generation proved to be far more successful in bringing about change. The Married Women's Property Committee pushed legislative reform of married women's property law in 1870 and 1882 through organising petitions and lobbying politicians. For example, the Married Women's Property Committee brought pressure to bear in the period prior to the passing of the Married Women's Property Act 1870 . They presented twenty nine petitions containing a total of 33,000 signatures to Parliament in $1868 .{ }^{48}$ In 1869 , they submitted a further 113 petitions

42 Smith 2007: 8.

43 Robson 1990: 101.

44 Mill 1984b: 296-297.

45 Idem at 284.

46 Holcombe 1983: 108.

47 Idem at 118-147.

48 Idem at 145. 
with more than 42,000 signatures to the House of Commons and seventy petitions containing a total of 30,000 signatures to the House of Lords ${ }^{49}$ This was the beginning of an effective and organised feminist movement in the late nineteenth century.

In 1868, George Shaw-Lefevre introduced the Married Women's Property Bill in the House of Commons that was co-sponsored by Mill and Russell Gurney for its first reading. ${ }^{50}$ The Bill was briefly considered by the select committee, but it was recommended that another select committee be appointed after the upcoming general election. ${ }^{51}$ By the end of the year, the Liberals had defeated the Conservatives in the general election with William Ewart Gladstone becoming Prime Minister. Although Mill lost his own seat, there were many newly elected MPs who were sympathetic to the advancement of women's rights. ${ }^{52}$ In 1869, Gurney re-introduced the same Bill that Shaw-Lefevre presented a year before during the first reading, which was co-sponsored by Jacob Bright and Thomas Emerson Headlam. ${ }^{53}$ The Bill proposed to grant married women equal rights to own property in their own name at common law. A rival Bill was presented by an opponent of reform Henry Cecil Raikes in an attempt to block Gurney's Bill. Raikes proposed to extend equitable rights over property for all married women. The aim was to provide legal recognition to a settlement that had been made upon marriage of which the local municipal authority would become the trustee of the wife's property..$^{54}$ The proposal was complicated and would have failed to recognise the common law property rights of married women. In 1870, both of the Bills were considered by the House of Commons during their second reading, but Raikes' Bill was defeated and Gurney's Bill prevailed..$^{55}$

The Bill then proceeded to the House of Lords where it was met with overwhelming disapproval. Lord Penzance, who had been Judge Ordinary of the Court for Divorce and Matrimonial Causes for seven years at the time of the debate, believed that the Bill "would subvert the principle on which the marriage relation had hitherto stood, and its tendency would be to cause increased discord and separation". ${ }^{56}$ Lord Westbury also opposed the Bill and was concerned that married women would be tempted to purchase jewellery at the expense of looking after their children. ${ }^{57}$ The tone of these comments reflect the sense of paranoia felt by many parliamentarians at the time. Their main concern was to uphold the traditional gender roles that had hitherto perpetuated discrimination against women over matrimonial property and divorce. On the other hand, The Times recognised that the Bill was non-partisan and

49 Ibid.

50 HC Debate 21 Apr 1868, vol 191, cols 1015-1025.

51 Holcombe 1983: 168.

52 Idem at 169.

53 HC Debate 25 Feb 1869, vol 194, col 331.

54 HC Debate 21 Jul 1869, vol 198, cols 402-403.

55 HC Debate 8 May 1870, vol 201, cols 878-892.

56 HL Debate 21 Jun 1870, vol 202, col 603.

57 Idem at cols 606-608. 
"it simply secures for the poor a justice already attained by the rich" ${ }^{58}$ The Bill was significantly amended during the Lords Select Committee. The amended Bill allowed married women to keep their earnings, saving deposits and some property coming from estates of a deceased. ${ }^{59}$ The original Bill became almost unrecognisable. It was now a compromise, albeit one skewed in the favour of the conservatives rather than the reformers.

When the Bill returned to the House of Commons for debate, Gurney - acting on the advice of the Married Women's Property Committee - urged that the amended Bill be accepted so there was at least some progress made on this issue. ${ }^{60}$ The British suffragette Lydia Becker critically remarked that the 1870 parliamentary debates "throughout assumed that the matter must be settled according to men's notions of what was just and expedient for women" ${ }^{61}$ Although the amendments had enraged supporters of the original Bill, Gurney decided that it would be better to get some legislation passed on married women's property rights rather than risk delay and face another embarrassing defeat. However, Gurney defiantly stated that "legislation on this subject could not end with this Bill, as there would yet remain much to be remedied" ${ }^{62}$ The Bill passed the House of Commons and received Royal Assent on 9 August 1869. The Married Women's Property Act 1870 allowed all married women to keep their wages and earnings gained from their own exercise of literary, artistic and scientific skill, ${ }^{63}$ inherit minor legacies received on intestacy of next of kin for up to $£ 200,{ }^{64}$ and retain savings kept on deposit. ${ }^{65}$ The Act was Mill's last major successful law reform, but the change was only a piecemeal law and there was still a demand for the absolute right of feme sole for all married women.

\section{The Married Women's Property Act 1882}

The 1870 Act fell short of the expectation of the reformers and they continued to campaign for complete legal rights to property for married women. Although Mill passed away in 1873, the campaign for comprehensive law reform of married women's property continued by feminists and progressive politicians alike. His influence provided the political drive and the philosophical rationale to continue the push for law reform. A minor amendment was made in 1874 under the Married Women's Property Act (1870) Amendment Act 1874. The Act made the husband liable for the wife's pre-nuptial debts and assets he had received upon entering into

58 Anon 1870b: 9.

59 HL Debate 18 Jul 1870, vol 203, cols 395-401.

60 HC Debate 3 Aug 1870, vol 203, col 1488.

61 Becker 1872: 57.

62 Ibid.

63 Married Women's Property Act 1870, s 1.

64 Idem $\mathrm{s} 7$.

65 Idem ss 2-5. 
the marriage. This remedied the situation of creditors being unable to recover the debts of separated married women. Hence, it became known as the "Creditor's Bill". ${ }^{66}$ The 1870 and 1874 Acts dampened the push for reform in the 1870 s. It was only during the early 1880 s that the legal status of married women's property rights was once again challenged. In 1880, William Gladstone's Liberal Party won the general election and ended six years of Conservative rule under the premiership of Benjamin Disraeli. This proved to be a turning point as the Liberals were more sympathetic than the Conservatives to reforming married women's property law. Although Gladstone opposed the introduction of civil divorce ${ }^{67}$ and women's suffrage,${ }^{68}$ he was willing to tolerate reform on matrimonial property rights for women as long as it did not have a major impact on the traditional structures of family life. ${ }^{69}$

In May 1880, the Liberal MP John Hinde Palmer introduced a Married Women's Property Bill for England. ${ }^{70}$ His colleague George Anderson introduced an equivalent Bill for Scotland on the same day. ${ }^{71}$ The Bills both proposed to grant all married women the full rights of feme sole in England and Scotland respectively. The Bills would have entitled married women to legally own property, to enter into contracts where a married woman could sue and be sued, and to be personally liable for her own torts. In June 1880, both of the Bills were heard together for their second reading. The Attorney-General, Sir Henry James (later Lord James of Hereford) expressed the Liberal Government's support for the Bills in principle, which helped both Bills pass the second reading without division. ${ }^{72}$ Despite a promising start, the Bills did not proceed any further. Sir George Campbell, a Scottish Liberal MP, became the leading opponent of matrimonial property law reform based on his socially conservative views on gender roles. He entered a notice of opposition to the Bills and successfully forced their withdrawal under the half-past-twelve rule. ${ }^{73}$ This was a procedural device that prohibited the introduction of opposed business past $12.30 \mathrm{am} .{ }^{74}$ Since it was late in the parliamentary year, the issue of married women's property rights was not revisited again in 1880 .

The year 1881 proved to be more auspicious for campaigners of married women's property rights. The Scottish and English Married Women's Property Bills were introduced together again and both passed their second readings without division on 13 January $1881 .{ }^{75}$ The Scottish Bill quickly passed both houses of

Shanley 1989: 104.

Kha \& Swain 2016: 318.

Van Wingerden 1999: 52.

Isba 2006: 151-152.

HC Debate, 21 May 1880, vol 252, col 293.

Idem at col 295.

HC Debate, 9 Jun 1880, vol 252, cols 1533-1545.

Shanley 1989: 122.

Vieira 2015: 92.

HC Debate, 13 Jan 1881, vol 257, cols 706-714. 
Parliament and received Royal Assent on 18 July 1881, becoming the Married Women's Property (Scotland) Act 1881. The Scottish Bill was able to pass speedily with the support of the Lord Advocate, John McClaren ${ }^{76}$ However, the English Bill was obstructed from further debate by socially conservative opponents in the 1881 parliamentary debates. This led to the continued postponing of the Bill until it was forced to be withdrawn. Despite the temporary setbacks, the Lord Chancellor, Lord Selborne, gradually came to support the introduction of the English Bill. This was somewhat surprising as he was known to have opposed married women's property rights in a speech he delivered to the Judicial Society in $1870 .{ }^{77}$ Lee Holcombe states "[t]hat the conservative-minded Lord Chancellor had become a convert to the cause of women's rights is extremely doubtful". ${ }^{78}$ Selborne's support for married women's property rights stemmed from his desire to see the consolidation of the 1870 and 1874 Acts. ${ }^{79}$ In fact, Selborne introduced the Scottish Bill, whereby he outlined that the Bill's purpose was to "carry out the same process of enlarging the wives' legal rights" ${ }^{80}$ Selborne realised that further matrimonial property law reform was an inevitable consequence of the introduction of the 1870 Act and wider law reform.

In February 1882, Selborne introduced the English Bill into the House of Lords, where it was finally adopted as official Government policy. ${ }^{81}$ This was a turning point as Selborne was determined to finally get the law passed by introducing the Bill to the House of Lords himself. This was a clear example of the critical importance of Government support in bringing about reform, especially on issues of social sensitivity. The Government's support for the Bill was largely uncontroversial and its passing was "almost unobserved by the mass of the persons whom it will affect" ${ }^{82}$ The Bill passed its second reading in March, ${ }^{83}$ and its third reading in the House of Lords in May. ${ }^{84}$ The Bill was then sent to the House of Commons. In June, Osborne Morgan introduced the Bill into the House of Commons on behalf of the Government. ${ }^{85}$ It passed its second reading without division and without debate. ${ }^{86}$ During the third reading, Sir George Campbell spoke against the Bill claiming it will create a "social revolution," but he was met with laughter and cries of "Oh, oh!" and "No, no!" $" 87$ The Bill passed its third reading with minor amendments on 15 August. ${ }^{88}$

HC Debate, 29 Apr 1881, vol 260, cols 1523-1525.

Anon 1870a: 10.

Holcombe 1983: 198.

HL Debate, 7 Mar 1882, vol 267, col 316.

HL Debate, 27 May 1881, vol 261, col 1439.

HL Debate, 14 Feb 1882, vol 266, col 626.

Anon 1882: 9.

HL Debate, 7 Mar 1882, vol 267, cols 316-317.

HL Debate, 19 May 1882, vol 269, col 1066.

HC Debate, 2 Jun 1882, vol 269, col 1932.

HC Debate, 8 Jun 1882, vol 270, col 464.

HC Debate, 11 Aug 1882, vol 273, cols 1603-1605.

HC Debate, 15 Aug 1882, vol 273, cols 1844-1847. 
It received royal assent on 18 August, becoming the Married Women's Property Act 1882.

Although the 1882 Act allowed married women to have the same rights of feme sole as unmarried women, the Act did not completely redress the issues of married women's property rights. ${ }^{89}$ The rights of a married woman were described using the language of equity. Section 1(2) of the Married Women's Property Act 1882 states that "[a] married woman shall be capable of entering into and rendering herself liable in respect of and to the extent of her separate property on any contract". ${ }^{90}$ Therefore, the wife's liability was proprietary rather than personal in contracts and torts. ${ }^{91}$ Furthermore, the husband was still liable for the torts of the wife committed by her during coverture under common law..$^{92}$

Nonetheless, the reform of married women's property rights through the 1870 and 1882 Acts fulfilled the longstanding dreams of Mill and many English feminist campaigners. The law reform of married women's property rights had a domino effect and challenged other areas where women faced sex discrimination in the law, such as the double standard in the grounds for divorce. William Cornish states that "[i]n truth, both [the 1870 and 1882] Acts were the upshot of sharp warfare about the very core of Victorian marriage". ${ }^{93}$ Indeed, equality on the issue of matrimonial property law between husbands and wives challenged the existing double standards under divorce law. If a married woman could have equal access to matrimonial property, then the question why women could not have equal access to divorce would inevitably be asked. The shifting views on the legal rights of women and the growing frustrations with divorce law contributed to the growing clamour for divorce reform.

\section{Divorce law reform}

Mill strongly advocated for the introduction of civil divorce, but more importantly the liberty to dissolve marriage on equal terms. In the 1850 s, there were more and more individuals calling for the reform of the divorce law. ${ }^{9} 4$ In a letter dated November 1855, John Stuart Mill strongly advocated for civil divorce to be introduced on equal terms:

My Opinion on Divorce is that though any relaxation of the irrevocability of marriage would be an improvement, nothing ought to be ultimately rested in, short of entire freedom on both sides to dissolve this like any other partnership. ${ }^{95}$

89 Cretney 2003: 97-100; Holcombe 1983: 201-202; Shanley 1989: 124-130.

90 Emphasis added.

91 The Married Women's Property Act 1882 represented the fusion of common law and equity. See Holcombe 1983: 202.

92 Edwards v Porter [1925] AC 1.

93 Cornish 2010: 766.

94 Kha \& Swain 2016: 309-310.

95 Mill 1972: 500. 
Once the Matrimonial Causes Act 1857 came into effect, it ended the de facto prohibition of divorce and saw the introduction of civil divorce. However, it created a double standard between husbands and wives. A husband only had to prove his wife's adultery as a prerequisite for the dissolution of marriage. On the other hand, a wife not only had to prove the husband's adultery, but also "aggravated enormity". This included incest, bigamy, cruelty to the wife, depravity of the husband (eg rape, sodomy and bestiality) or the desertion of the husband for at least two years without reasonable excuse. ${ }^{96}$ Despite the enormous legal barriers, approximately forty percent of divorce petitioners in the period between 1858 and 1900 were wives. ${ }^{97}$ Mill held a unique view of marriage as the ultimate expression of a friendship between a man and a woman. It is important to appreciate his views on marriage, since it ultimately influenced his views on the grounds for divorce.

\section{Marriage as friendship}

Harriet Taylor was married to Mill and she had a profound role in ideologically influencing Mill, which is most evident in the publications that they published on the topic of women's rights either separately or together. ${ }^{98}$ Mill published $O n$ Marriage in 1833, where he argued that it was absurd to talk of equality while marriage remained indissoluble. ${ }^{99}$ In the same year, Taylor also wrote a publication entitled On Marriage, where she criticised the societal expectation of women's roles in society. ${ }^{100}$ She argued that women were merely seen as objects that gain their usefulness in marriage, and criticised the law's failure to remedy women "who suffer most from its evil" by denying individuals the legal right to divorce. ${ }^{101}$ In both of these publications, Mill and Taylor advocated for women's equality and law reform in the areas of marriage and divorce. They also co-authored the Papers on Women's Rights between 1847 and 1850, and advocated for "the negation of all distinctions among persons, grounded on the accidental circumstance of sex". ${ }^{102}$

Mill was clearly influenced by his wife and begins The Subjection of Women with a radical polemic:

That the principle which regulates the existing social relations between the two sexes the legal subordination of one sex to the other - is wrong itself, and now one of the chief hindrances to human improvement; and that it ought to be replaced by a principle of perfect equality, admitting no power or privilege on the one side, nor disability on the other. ${ }^{103}$

96 Matrimonial Causes Act 1857, s 27.

97 Cretney 2003: 169.

98 Mendus 1994: 292.

99 Mill 1984a: 42.

100 Taylor 1984: 376.

101 Ibid.

102 Taylor Mill and Mill 1984: 386.

103 Mill 1984b: 261. 
This was a very provocative statement in the nineteenth century. In theory, women were free to marry whomever they pleased under the law. In Hyde v Hyde and Woodmansee, Sir James Wilde (later Lord Penzance) delivered a landmark judgment: "I conceive that marriage, as understood in Christendom, may for this purpose be defined as the voluntary union for life of one man and one woman, to the exclusion of all others." 104 In practice, however, women had little choice in the matter despite the supposed voluntariness. As Shanley points out, "women were not free within marriage, and they were not truly free not to marry". ${ }^{105}$ Women had no access to university education, they were practically barred from most professions and they could not own property in their own right. Therefore, women were dependent on men in order to sustain a living.

Mill describes the consequences of marriage for women as "the primitive state of slavery lasting on". ${ }^{106}$ Sir James Wilde's allusion to "Christendom" in his judgment is indicative of the prevailing view at the time that marriage was seen as upholding a particular Christian view of society. The fate of women is predestined in the Bible: "[T]hy desire shall be to thy husband, and he shall rule over thee." ${ }^{107}$ The Biblical understanding of women was later interpreted in a self-fulfilling prophecy by the renowned English eighteenth century jurist Sir William Blackstone into the doctrine of coverture: "By marriage, the husband and wife are one person in law: that is, the very being or legal existence of the woman is suspended during the marriage, or at least is incorporated and consolidated into that of the husband." 108 Therefore, in Victorian England a woman had almost no independent legal rights as these were subsumed under her husband.

Mill was more controversial for challenging the traditional understanding of gender roles rather than for advocating for law reform. Mill believed that "society in equality is its normal state". ${ }^{109} \mathrm{He}$ argued that the marriage laws were in a primitive state. In order for society to evolve and reach its desired point, it must recognise the equality of women. ${ }^{110}$ Therefore, Mill was critical of the idea of a natural hierarchy, whereby men were viewed as the ontological superiors of women. He rejected the assertion that female subjugation by men was "natural." Instead, he argued that this was the result of the political and social apparatuses of control, which made women dependent on men based on men's paranoia of gender equality threatening their dominant standing in law and society. ${ }^{111}$ These views were considered to be rather

104 (1866) LR 1 P\&D 130, 133.

105 Shanley 1998: 401.

106 Mill 1984b: 264.

107 Genesis 3:16 (KJV).

108 Blackstone 2016: 284.

109 Mill 1984b: 294.

110 Idem at 336.

111 Idem at 340. 
radical during his time. ${ }^{12}$ Mill also believed the subjection of women could not be extirpated through the law alone, but legal change could help reform the treatment of women and the thinking of men. Some of the moral excesses of Victorian England marriage law included the legality of marital rape, the paucity of domestic violence legislation and the husband exercising almost unbridled rights over his wife's property.

Mill envisaged marriage as a friendship and believed such an outlook would help ameliorate men's fears of gender equality in the law and improve the overall status of women. ${ }^{113}$ Mill's writings helped to invigorate the campaign for the reform of married women's property rights. According to Stephen Cretney, Mill's publication of The Subjection of Women in 1869 "gave powerful intellectual stimulus to the reform movement". ${ }^{114}$ The initial aim was to separate the property of husbands and wives. However, this was not achieved until the enactment of the Married Women's Property Act 1882. The Married Women's Property Act 1870 was amended when it was a Bill so much so it only granted married women the legal right to own property earned from their employment, ${ }^{115}$ saving deposits ${ }^{116}$ and small legacies. ${ }^{117}$ A major theme in The Subjection of Women is friendship as "the ideal of marriage" with marriage serving as "a foundation for solid friendship". ${ }^{118}$ Although Mill supported law reform in the areas of marriage and divorce, he always believed in the institution of marriage playing an important role in fostering the relationship between a man and a woman and for the upbringing of children. Mill states that "[m]arriage is not an institution designed for a select few ... The tie of affection and obligation to a wife and children is very strong with those whose general social feelings are strong". ${ }^{119}$ Marriage as a friendship was a creative way to challenge traditional understandings of marriage.

The concept of marriage was not only a legal one but also religious. The Church of England once had an exclusive monopoly over the solemnisation of marriages. This was promoted by Lord Hardwicke's Marriage Act 1753, which gave sole legal recognition to marriages solemnised by the Church of England. ${ }^{120}$ All other marriages solemnised by other denominations, except Quaker and Jewish marriages ${ }^{121}$ were not legally recognised until the Marriage Act 1836 came into effect. The Marriage

112 Ward \& McGlynn 2016: 229.

113 Mill 1984b: 334.

114 Cretney 2003: 96.

115 Married Women's Property Act 1870, s 1.

116 Married Women's Property Act 1870, s 2.

117 A married woman was only entitled to "any sum of money not exceeding two hundred pounds under any deed or will”. See Married Women's Property Act 1870, s 7.

118 Mill 1984b: 334.

119 Idem at 287.

120 Probert 2009: 228-229.

121 Idem at 232-236. 
Act 1836 created civil weddings and allowed for marriages to be solemnised in Nonconformist and Roman Catholic churches. ${ }^{122}$ Thus, it repealed the Marriage Act 1753 and ended the Church of England's monopoly over the solemnisation of marriage. Marriage was traditionally seen as a sacramental union that promoted a Christian understanding of the role of men and women on earth. "The Form of Solemnization of Matrimony" in the Book of Common Prayer of 1662 describes "the causes for which Matrimony was ordained":

First, It was ordained for the procreation of children, to be brought up in the fear and nurture of the Lord, and to the praise of his holy Name. Secondly, It was ordained for a remedy against sin, and to avoid fornication; that such persons as have not the gift of continency might marry, and keep themselves undefiled members of Christ's body. Thirdly, It was ordained for the mutual society, help, and comfort, that the one ought to have of the other, both in prosperity and adversity. ${ }^{123}$

This can be summed up as marriage having the purpose of giving birth and raising children, safeguarding against sexual relations outside of marriage and for the mutual promotion of the welfare of the married couple. Despite the enactment of the Marriage Act 1836, the civil definition of marriage still echoed the spirit of the Book of Common Prayer. Sir James Wilde in Hyde v Hyde and Woodmansee relied on the Christian faith as a source of doctrine to deny the recognition of polygamous relationships in "Christendom". ${ }^{124}$ On the one hand, marriage was still seen as fundamentally an act grounded in Christian dogma. On the other hand, the description of marriage as something that can be "contracted" indicated the spirit of the times. Marriage was beginning to be characterised by the law as a secular contractual relationship in consonance with Reformation thinking rather than as a sacramental union, ${ }^{125}$ which could be ended on the grounds of matrimonial causes for divorce in the Matrimonial Causes Act 1857.

It was within this legal historical context that Mill broke with the status quo by writing The Subjection of Women. Friendship was never seen as a pre-requisite to marriage, merely an incidence of marriage for those fortunate to marry a person of compatible disposition. Mill simply emphasised the humanity of marriage rather than ecclesiastical sacramentality or the judicial legality of marriage. Marriage as friendship was seen as promoting harmony in the private sphere that would naturally manifest itself in the public square. Mill rejected the dichotomy of public and private. Gender equality in the law could not occur if men acted brutally towards their wives in the private sphere, while acting with superficial civility in the public square. Mill believed that the "true virtue of human beings is the fitness to live 
together as equals". ${ }^{126}$ Thus, without friendship in marriage, law reform in the area of sex discrimination would be impossible and society could not progress. Mill's ideas on marriage quite naturally shaped his beliefs on divorce, namely that where friendship in a marriage no longer exists the relationship should be allowed to be dissolved through divorce.

\section{The sexual double standard of divorce}

Mill gave an equivocal response on the question of whether domestic violence was a suitable ground for a wife to divorce her husband:

I am not saying that she ought to be allowed this privilege. That is a totally different consideration. The question of divorce, in the sense involving liberty of remarriage, is one into which it is foreign to my purpose to enter. ${ }^{127}$

Mill seems to be more concerned with the social issue of female subjugation than the legal issue of sex discrimination. Susan Mendus argues that Mill's contemporaries in the nineteenth century viewed him as "both moral and radical," but twentieth century commentators confuse Mill as simply an apologist for liberalism who saw law reform as a means of achieving his ends. ${ }^{128}$ Another possible explanation for Mill's reticence on the topic of women's divorce may be found in his belief in the importance of marriage. Although Mill condemned the legal nature of marriage as "the only actual bondage known to our law", ${ }^{129}$ he held a positive view of a good marriage as the ultimate friendship that celebrates a loving companionship and facilitates a stable family life for children. ${ }^{130}$ If friendship no longer existed in a marriage, then Mill believed "the happiness of both parties would be greatly promoted by a dissolution of marriage". ${ }^{131}$ Mill expressed the latent views held by many in society that an irretrievably broken down marriage should be dissolved. However, Mill was a marginal voice during the debate on the reform of divorce law.

In 1854, Barbara Leigh Smith published a provocative pamphlet calling for divorce and matrimonial property law reform. ${ }^{132}$ She criticised the doctrine of coverture: "A woman's body belongs to her husband; she is in his custody, and he can enforce his right by a writ of habeas corpus." 133 She was also critical of the inaccessibility of divorce: "The expenses of only a common divorce bill are between six hundred and seven hundred pounds, which makes the possibility of release from

126 Mill 1984b: 294.

127 Idem at 285.

128 Mendus 1994: 287.

129 Mill 1984b: 323.

130 Idem at 334.

131 Mill 1984a: 45.

132 Leigh Smith 1856.

133 Idem at 4. 
the matrimonial bond a privilege of the rich." ${ }^{134}$ Her efforts attracted support from the Law Amendment Society after Liberal MP Richard Monckton Milnes submitted Leigh Smith's pamphlet to the Law Amendment Society. ${ }^{135}$ The society was founded by Lord Brougham in $1844^{136}$ to support his law reform agenda, ${ }^{137}$ and to make a case for reform through its quarterly journal The Law Review. ${ }^{138}$

In 1856, the Law Amendment Society endorsed Leigh Smith's pamphlet and published a report supporting the right of married women to own property and to legally enter contracts in line with their own aim to fuse equity and common law. ${ }^{139}$ Married women could already practically own property as a beneficiary under a trust, but the status of feme sole under law would give married women separate legal personality and financial independence. ${ }^{140}$ The Law Amendment Society believed that the inconsistency between equity and common law found in matrimonial property law only made the law unnecessarily complicated, ${ }^{141}$ and supported the introduction of civil divorce with the goal of making divorce more accessible as a matter of legal equality. ${ }^{142}$ Early feminists supported the introduction of civil divorce and making divorce more accessible on the grounds of equality. ${ }^{143}$ Leigh Smith, along with likeminded friends Mary Howitt and Bessie Parkes, established the English Women's Journal (1858-1864) and the Langham Place Circle (1858-1866) to push the cause of "liberal feminism". ${ }^{144}$

Mill was disappointed with the divorce law - at least in principle. He criticised the law reform as "feeble attempts" to repress domestic violence. ${ }^{145}$ More significantly, Mill found the hypocrisy of the law particularly abject: "If she leaves her husband, she can take nothing with her, neither her children nor anything which is rightfully her own. If he chooses, he can compel her to return, by law, or by physical force."146 In order to remedy some of the issues mentioned, Mill believed that courts should intervene and determine the best interests of the child in the event of an unamicable

134 Idem at 6. The figure is supported by the findings of the Campbell Commission. See "The First Report of the Commissioners Appointed by Her Majesty to Enquire into the Law of Divorce, and More Particularly into the Mode of Obtaining Divorces A Vinculo Matrimonii” British Parliamentary Papers 40 (1852-1853): 270.

135 Shanley 1989: 34.

136 Law Amendment Society 1856; Shanley 1989: 34-35.

137 Garratt 1935: 326.

138 Idem at 332.

139 Law Amendment Society 1856.

140 Holcombe 1983: 38.

141 Law Amendment Society 1852.

142 Wroath 1998: 130.

143 Ibid.

144 Murdoch 2014: 8; Herstein 1993.

145 Mill 1984b: 287.

146 Idem at 285. 
divorce, ${ }^{147}$ and women should have the legal right to own property. ${ }^{148}$ In regards to divorce, Mill recognised a remedy in the judiciary: "It is only legal separation by a decree of a court of justice, which entitles her to live apart." ${ }^{149}$ However, the establishment of the Court for Divorce and Matrimonial Causes did not immediately provide access to divorce for all married couples. Cretney describes the unpopularity of the divorce law in late Victorian England:

By the beginning of the twentieth century the hardship and injustice of the law was widely appreciated, whilst the fact that the law seemed to enshrine a double standard of morality ... was an easy target for the increasingly vocal feminist movement. ${ }^{150}$

\section{Conclusion}

Mill was an agent provocateur on issues of morality, yet it outwardly seems inexplicable that his stance on moral issues did not translate into a practical argument on broadening the grounds for divorce. Indeed, Mill was one of the greatest activist philosophers in the nineteenth century, outraging most social commentators of his day with the idea that women could and should be equal to men. Mill's reticence on this topic can be explained based on his confidence in the institution of marriage. Mill's view of marriage as friendship is a positive one that celebrates a loving relationship that helps foster a stable family life for children. Mill believed that if friendship did not exist in marriage, then "the happiness of both parties would be greatly promoted by a dissolution of marriage". ${ }^{151}$ It is important to remember that divorce was stigmatised and rare in Victorian England. Although Mill condemned the legal and social nature of marriage as "the only actual bondage known to our law", ${ }^{152}$ he never condemned the institutional idea of marriage itself. Instead, he extolled the virtues of marriage in solemnising the serendipity of friendship between a man and a woman.

Mill believed that gender equality was a moral issue that could be remedied to some extent through law reform. However, he believed that law reform could only go so far. Discrimination against women in the law was merely a symptom of the wider sexist thinking that was pervasive among men in nineteenth century Victorian England. Change had to occur in the minds of men. The treatment of women had to

147 Mill 1972: 500.

148 Mill 1984b: 296-297.

149 Idem at 285.

150 Cretney 2003: 202.

151 Mill 1984a: 45.

152 Mill 1984b: 323. 
improve in order to change the litany of injustices both legal and moral perpetrated against women. The Subjection of Women was Mill's call for reform on the mistreatment of women in law and society. In particular, the call to end the doctrine of coverture, the abolition of the double standards to the grounds for divorce, and the legal right for women to own property. These ideas formed the foundation for law reform from the late nineteenth century onwards. Although Mill was radical in his day, he still upheld the institution of marriage and encouraged the traditional division of labour with men as breadwinners and women as the primary caretakers of children. Mill believed in gender equality, but also recognised the importance of men and women playing their complimentary roles.

\section{BIBLIOGRAPHY}

Anon (1870a) "The rights and liabilities of married women" The Times 27 January: 10

Anon (1870b) "The session has received the second of its three warnings" The Times 1 June: 9

Anon (1882) "Quietly, and almost unobserved by the mass of the persons whom it will affect" The Times 17 August: 9

Becker, Lydia (1872) “The political disabilities of women” The Westminster Review 41(1): 50-70

Blackstone, William (2016) in David Lemmings (ed) Commentaries on the Laws of England, vol 1 (Oxford)

Capaldi, Nicholas (2004) John Stuart Mill: A Biography (Cambridge)

Church of England (2004) The Book of Common Prayer (Cambridge)

Cornish, William (2010) "Wives: The quest for civil independence" in William Cornish, J Stuart Anderson, Ray Cocks, Michael Lobban, Patrick Polden \& Keith Smith (eds) The Oxford History of the Laws of England vol 13 (Oxford): 757-766

Cretney, Stephen (2003) Family Law in the Twentieth Century (Oxford)

Dicey, AV (1905) Lectures on the Relation between Law and Public Opinion in England during the Nineteenth Century (London)

Eisenstein, Zillah (1981) The Radical Future of Liberal Feminism (New York)

Garratt, GT (1935) Lord Brougham (London)

Glassman, Peter (1985) J.S. Mill: The Evolution of a Genius (Gainesville)

Hale, Matthew (1739) The History of the Pleas of the Crown vol 1 (London)

Herstein, Sheila (1993) "The Langham Place Circle and Feminist Periodicals of the 1860s" Victorian Periodicals Review 26: 24-27

Himmelfarb, Gertrude (1974) On Liberty and Liberalism (New York)

Holcombe, Lee (1983) Wives and Property: Reform of the Married Women's Property Law in Nineteenth-Century England (Toronto)

Holmes, Ann Sumner (1995) “The double standard in the English divorce laws, 1857-1923" Law and Social Inquiry 20(2): 601-620 
Isba, Anna (2006) Gladstone and Women (New York)

Kha, Henry \& Warren Swain (2016) "The enactment of the Matrimonial Causes Act 1857: The Campbell Commission and the Parliamentary Debates" J of Legal History 37(3): 303-330

Kinzer, Bruce, Ann Robson \& John Robson (1992) A Moralist in and Out of Parliament: John Stuart Mill at Westminster, 1865-1868 (Toronto)

Law Amendment Society (1852) "Fusion of Law and Equity" Law Review and Quarterly J of British and Foreign Jurisprudence 16(1): 184-189

Law Amendment Society (1856) "Report of the Personal Laws Committee (of the Law Amendment Society) on the Laws Relating to the Property of Married Women" The Westminster Review 66: $331-360$

Leigh Smith, Barbara (1856) A Brief Summary, in Plain Language, of the Most Important Laws Concerning Women: Together with a Few Observations Thereon (London)

Mendus, Susan (1994) "John Stuart Mill and Harriet Taylor on women and marriage" Utilitas 6(2): $287-299$

Mill, John Stuart (1972) "Letter 253" in Francis Mineka and Dwight Lindley (eds) The Later Letters of John Stuart Mill 1849-1873 Part I, vol 14 (Toronto): 499-501

Mill, John Stuart (1977) “On liberty” in John Robson (ed) Essays on Politics and Society, vol 18 (Toronto): 213-310

Mill, John Stuart (1984a) “On Marriage” in John Robson (ed) Essays on Equality, Law, and Education, Collected Works, vol 21 (Toronto): 35-50

Mill, John Stuart (1984b) "The subjection of women" in John Robson (ed) Essays on Equality, Law, and Education, Collected Works, vol 21 (Toronto): 259-340

Miller, Dale (2017) "Mill on the family" in Christopher MacLeod and Dale Miller (eds) $A$ Companion to Mill (Chichester): 472-487

Morales, Maria (2005) “The corrupting influence of power" in Maria Morales (ed) The Subjection of Women: Critical Essays (Lanham): 98-113

Morales, Maria (2007) "Rational freedom in John Stuart Mill's feminism" in Nadia Urbinati \& Alex Zakaras (eds) J.S. Mill's Political Thought: A Bicentennial Reassessment (Cambridge): 43-65

Murdoch, Lydia (2014) Daily Life of Victorian Women (Santa Barbara)

Parry, Jonathan (1993) The Rise and Fall of Liberal Government in Victorian Britain (New Haven)

Phillips, John A \& Charles Wetherell (1995) "The Great Reform Act of 1832 and the political modernization of England" The American Historical Review 100(2): 411-436

Probert, Rebecca (1999a) "The controversy of equality and the Matrimonial Causes Act 1923" Child and Family Law Quarterly 11: 33-42

Probert, Rebecca (1999b) "The double standard of morality in the Divorce and Matrimonial Causes Act 1857" Anglo-American Law Review 28: 73-86

Probert, Rebecca (2009) Marriage Law and Practice in the Long Eighteenth Century (Cambridge)

Reeves, Richard (2007) John Stuart Mill: Victorian Firebrand (London)

Rheinstein, Max (1972) Marriage Stability, Divorce and the Law (Chicago) 


\section{HENRY KHA}

Robson, Ann (1990) “No laughing matter: John Stuart Mill’s Establishment of Women's Suffrage as a Parliamentary Question" Utilitas 2(1): 88-101

Shanley, Mary Lyndon (1986) "Suffrage, protective labor legislation, and married women's property laws in England" Signs 12(1): 62-77

Shanley, Mary Lyndon (1989) Feminism, Marriage, and the Law in Victorian England, 1850 1895 (Princeton)

Shanley, Mary Lyndon (1998) “The subjection of women” in John Skorupski (ed) The Cambridge Companion to Mill (Cambridge): 396-422

Smith, Harold (2007) The British Women's Suffrage Campaign, 1866-1928 (Harlow)

Stone, Lawrence (1995) Road to Divorce: England 1530-1987 (Oxford)

Stretton, Tim \& Krista Kesselring (2013) "Introduction: Coverture \& Continuity" in Tim Stretton \& Krista Kesselring (eds) Married Women and the Law: Coverture in England and the Common Law World (Montreal): 3-23

Taylor, Harriet (1984) “On Marriage” in John Robson (ed) Essays on Equality, Law, and Education, Collected Works, vol 21 (Toronto): 375-377

Taylor Mill, Harriet and John Stuart Mill (1984) "Papers on Women's Rights" in John Robson (ed) Essays on Equality, Law, and Education, Collected Works, vol 21 (Toronto): 378-392

Tong, Rosemarie (2009) Feminist Thought (Boulder)

Tulloch, Gail (1989) Mill and Sexual Equality (Hemel Hempstead)

van Wingerden, Sophia A (1999) The Women's Suffrage Movement in Britain, 1866-1928 (New York)

Vieira, Ryan (2015) Time and Politics: Parliament and the Culture of Modernity in Britain and the British World (Oxford)

Ward, Ian \& Claire McGlynn (2016) "Women, law and John Stuart Mill” Women's History Review 25(2): $227-253$

Wroath, John (1998) Until They are Seven: The Origins of Women's Legal Rights (Winchester)

\section{Case law}

Edwards v Porter [1925] AC 1

Hyde $v$ Hyde and Woodmansee (1866) LR 1 P\&D 130 
JOHN STUART MILL ON MATRIMONIAL PROPERTY AND DIVORCE LAW REFORM

\section{Legislation}

Married Women's Property Act 1870 (33 \& 34 Vict, c 93)

Married Women's Property Act (1870) Amendment Act 1874 (37 \& 38 Vict, c 50)

Married Women's Property (Scotland) Act 1881 (44 \& 45 Vict, c 21)

Married Women's Property Act 1882 (45 \& 46 Vict, c 75)

Matrimonial Causes Act 1857 (20 \& 21 Vict, c 85)

Matrimonial Causes Act 1923 (13 \& 14 Geo V, c 19)

Reform Act 1832 (2 \& 3 Wm IV, c 45)

Reform Act 1867 (30 \& 31 Vict, c 102) 